\title{
The paradox of the autonomy of Afro-descendants in the Colombian Pacific
}

\author{
Mireya E. Valencia Perafán
}

Ph.D. in Social Sciences, Professor at the University of Brasilia (UnB),

Brasilia, DF, Brazil

E-mail:mireya@unb.br

doi:10.18472/SustDeb.v10n3.2019. 27193

BOOK REVIEW

Claudia Leal. Landscapes of Freedom - Building a Postemancipation Society in the Rainforests of Western Colombia. Tucson: The University of Arizona Press. 2018. 336 p. ISBN - 13: 978-0-8165-36740 (cloth). US\$55.00. Figures, maps, graphs, tables, bibliography and index.

In Landscapes of Freedom, Claudia Leal successfully analyzes the economic and social evolution of Colombian Pacific and how it conditioned the current situation of the region. Based upon an environmental approach of social history, she uses the extractive economy and racialized areas as the main guiding concepts of her analysis to offer elements that help understand a crucial aspect of modern Latin America: the transition from slavery to freedom.

The contribution of this case study - a region and a problem forgotten in the historical map of African Latin America - is a pertinent reconstruction of the post-emacipation trajectory where a racialized landscape is designed with material transformations in the forest situation and the changes in the meanings attributed to them by authors who left historic accounts of the region.

The Colombian Pacific is one of the wettest regions of the planet, with a precipitation that can reach, on high Chocó, more than $8,000 \mathrm{~mm}$ of rain per year and 4,000 $\mathrm{mm}$ in the lowest regions (the Amazon receives $2,000 \mathrm{~mm} /$ year). Climatic conditions make this one of the regions of the world with the highest rate of endemism (phenomenon in which a species occurs only in one geographic region) and biodiversity.

What the author analyzes with richness of details and substance is that after the emancipation of the slaves, the communities of African descent reached a high degree of autonomy, much higher than any other similar groups in rural areas.

The main economic activity in the region, in the colonial period and after independence, was the extraction of gold using slave labor. However, the limited power of the slaveowners to impose work conditions and avoid escapes of the slaves, led to the slaves obtaining better work and life conditions. As the areas of gold production declined, slaves obtained their freedom mainly by purchasing their own liberty and, in the majority of cases, they continued as free people in the mining regions.

The lack of capital by the white mine-owners, made them try to rent the areas of exploration instead of investing in production. Hence, whites kept the mines profitable even after the end of slavery by renting the mines instead of paying the workers their salaries.

The lack of strict control over exploration of the gold veins allowed many afro-descendants to obtain resources to purchase their own freedom or that of their family members. In this context of loss in 
gold productivity and the lack of capital by the mine owners, initially in Choco and later throughout the region, increased the possibilities of a growing black population to have access to the mining areas.

Before slavery was totally abolished, the reduction in mining activity, combined with the lack of supplies encouraged many free blacks to produce food in small areas around the riverbanks where they cultivated sugar cane, tobacco and raised a few heads of cattle. Others worked as traveling traders, in transporting goods, in fishing and in crafts.

Around the middle of the $19^{\text {th }}$ Century, when slavery was abolished in Colombia, part of the blacks did nor remain in the mining areas and went to other areas attracted by opportunities of other forms of extractive activities. Among them were rubber and vegetable ivory (Tagua seeds, Phytelephas macroparpa palm) which had started to be commercialized in the world market. Similar to the miners, those that migrated and started to extract latex and the Tagua seeds, did so in an independent manner, without employers. Besides, they did not need to rent the areas of exploration because they worked in public areas over which the State had little or no control. Thus, the extractivist economy strengthened and expanded from underground to the forest and from the mining areas to the rest of the region.

What the author demonstrates is that the process of occupation of the region and the exploration, conditioned by the environment and by extrativism reveal an uncommon trajectory in the region of the Colombian Pacific if compared to the slaves in other regions due to the high levels of autonomy that they reached by not being subject to bosses or supervisors in the plantations.

Examining the access of the black population to extractivist activity allows us to understand how freedom was experimented and understood. To the afro-descendants, the legal condition of freedom acquired a concrete sense by giving them the possibility to determine what to do with their bodies and, at the same time, with their time and place in the Colombian Pacific.

Freed blacks enjoyed the freedom of movement, not only to move around in the forests, the rivers in canoes, but to choose where they wanted to live. The extent of the region, its richness and the low demographic density, allowed that some areas be occupied without conflict along the coast in the riverbanks.

The fact that this population enjoyed freedom and autonomy does not explain one paradox. The same initial marginality that empowered them, in the long run reduced the options and opportunities of this population. That is, their capacity to decide how to live. This led to low levels of education and income, made evident by recent economic and social indicators. Between 1990 and 2004, the region of Chocó was inhabited by $1 \%$ of the Colombian population, but generated only $0.4 \%$ of its GDP, rates that parallel those of education and welfare. In 2005, the percentage of people who could not read or write in Chocó was more than twice the national average.

The very particular post-emancipation trajectory of the region, therefore, is bittersweet, as the author states: at the same time in which liberty was catapulted, it was onerous in the long run. Marginalization allowed the black population to enjoy freedom, occupy, control and explore the rich coastal forest with an important cultural legacy that was under-evaluated, even despised, until it was recognized by the Colombian Constitution of 1991.

"Landscape of Freedom" situates the wettest tropical forest in the world in the socioeconomic evolution of the region after the end of slavery, emphasizing the relations between the environment and the afro-descendant population. It is, in this aspect, a reconstruction of the past of this population and a contribution to the Colombian national community so that it becomes more inclusive. 